\title{
Extended Release Dosage Form
}

National Cancer Institute

\section{Source}

National Cancer Institute. Extended Release Dosage Form. NCI Thesaurus. Code C42713.

A solid, semi-solid, solution or suspension designed to release active and/or inert ingredient(s) at a controlled, prolonged rate so as to reduce dosing frequency. 